\title{
PHARMACOLOGICAL STUDY ON THE EFFECT OF DICLAZURIL AND SEMDURAMICIN ON THE IMMUNE RESPONSE IN BRIOLERS
}

\author{
M. F. El dakroury and W. F. Resik
}

Animal Health Research Institute, provisional lab Kafer El-Sheikh Pharmacology

\begin{abstract}
The aim of the present work was to study the effect of two anticoccidial drugs namely diclazuril and semduramicin on the immune response of briolers. Birds were divided into three equal groups, each of 50 chicks. The $1^{\text {st }}$.group received semduramicin $(25$ ppm). The $2^{\text {nd }}$ group received diclazuril (1ppm) and $3^{\text {rd }}$ group received only basal ration (control). All groups were vaccinated against Newcastle virus at 18 days and were challenged with a virulent strain of ND at the ${ }^{21 \text { th }}$ day of age. Blood samples were collected from birds of each group at 25 days of the experiment. Five chickens of each group were slaughtered at the same age then the lymphoid organs (thymus, bursa and spleen) were carefully separated \&weighed and each organ relative weight was determined.Number of dead birds were recorded daily till the end of the experiment (at 45 day). It was observed that administration of diclazuril and semduramicin in recommended doses has no significant changes on blood cell count. Moreover, the obtained results indicated that both drugs had no significant effects on createnine and uric acid serum levels and on the activities of AST and ALT,. On the other hand, semduramicin induced a significant decrease in the phagocytic activity, serum globulin and HI titer. Additionally, semduramicin decreased the relative weights of bursa.
\end{abstract}




\section{INTRODUCTION}

Diclazuril is characterized by its strong anticoccidial activity and safety without causing prompt emergence of drug resistance in parasites (kutzer et al. 1988 and chapman 1989). Chickens for fattening tolerated a 25 -fold overdose of diclazuril for 37 days without any observable negative effects on performance, haematology, necropsy and histopathology (EFSA, 2011).

Kandeel (2002) studied the effect of diclazuril (0.5,1 and 2 ppm) as prophylactic and therapeutic treatment on broilers infected with Eimeria teneella. He observed significant decrease in total leucocytic count and increase in serum total protein, albumin and globulin at the $1^{\text {st }}, 2^{\text {nd }}$ and $3^{\text {rd }}$ weeks post coccidial infection in treated groups. More over, Hasan et al.(1999) recorded that diclazuril (2ppm) decreased the total leucocytic count, delayed hypersensitivity, lymphoid organs weight and humoral immune response to sheep RBcs.

Body weight and feed conversion were not significantly affected in birds fed diclazuril at 1,5 and $10 \mathrm{ppm}$ for 42 days in comparison with uninfected, unmedicated birds in floor pen studies. These studies demonstrated also that diclazuril was well tolerated up to 10 times the recommended dose of 1 ppm (Vanparijs et al., 1989).

Ionophores are generally safe and effective if used at recommended doses. However, ionophore toxicity might occur due to accidental overdoses, misuse, feed mixing errors as well as when combined factors lead to liver incapacity to fully metabolize them (Nebbia et al. 1999 and Chapman, 2001). On the other hand, Dowling (1992) reported that ionophores have a narrow range of safety and it is sometimes difficult to ensure an even distribution of the drug throughout the feed. 
Semduramicin is one of the polyether ionophores which considered one of the most widely used dugs in preventing coccidiosis in broilers. This drug is produced from actinomadura yumaensis (Tsou et al.1984 and Riviere et al., 2009) and its efficacy as anticoccidial dug was extensively investigated by many authers. (Falz et al 1988; Salischs and Shakshouk 1990 and Salisch and Friederichs 1991).

Abd El-Lateif (1993) tested the recommended and double dose of maduramicin on the immunity in broiler chickens. He found that on the 42 nd day of age both doses did not affect the total and differential leucocytic count, serum total proteins, serum albumin and albumin / globulin ratio as compared with control group. Moreover, Abo-Zahra (1997) reported that maduramicin decreased the protection of chickens against ND virus.

El-Kahkey (1998) studied the effect of semduramicin (25 ppm) on the immune response to Newcastle disease virus in broilers. He found that semduramicin induced no significant changes in both total and differential leucocytic count. Also, there was no significant changes in serum total proteins. On the other hand, Seif (2008) concluded that semduramicin (25ppm) had immunosuppressive effect on broiler. This effect was reflected through the recorded decrease in total leucocytic count and serum globulin.

This work was conducted to investigate the effects of adding diclazuril and semduramicin to the ration on the immune response of broilers. 


\section{MATERIAL AND METHODS}

\section{1- Diclazuril(Clinacox®):}

It is a synthetic anticoccidial drug developed and described by janssen pharmaceutica, Bulguim. Clinacox recommended at a level of $1 \mathrm{ppm}$

\section{2- Semduramicin(Aviax®):}

Aviax is an ionophorous anticoccidail developed and described by Pfizer. Egypt. Aviax recommended at a level of 25ppm

\section{Newcastle Challenge strain:}

A local velogenic viscerotropic strain of Newcastle Disease Virus(NDV), was obtained from the Veterinary institute for biological products and vaccines (Abbasia,Cairo).

\section{Experimental design:}

Ninety one day old Hubbard chicks were randomly divided into 3 equal groups, each of 30 chick. Group (1) received semduramicin (25ppm). Group (2) received diclazuril(1ppm). Group (3) was used as a control group. All birds were floor reared. The drinking water and ration were supplied ad libitum.

All groups were vaccinated against ND at 18 day old and were challenged with a virulent strain of ND at the $21^{\text {st }}$ day of age. At 25 day of the experiment, blood samples were collected from birds of each group. 5 chickens of each group were slaughtered at the same age then 
the lymphoid organs (thymus, bursa and spleen) were carefully separated \&weighed and each organ relative weight was determined. The experimental period lasted for 45 days. The total amount of feed intake was recorded.The final live body weight was obtained and the feed conversion was calculated (feed intake/ weight gain). Number of dead birds were also recorded throught out the experiment.

\section{Laboratory examinations:}

Phagocytic activity and phagocytic index were determined according to Barry et al. (1989). Total erythrocytic and leukocytic counts were done according to Natt and Herrick, (1952). Blood film was prepared and stained with Giemsa stain for differential leukocytic count according to schalm et al.,(1975).

Determination of serum total protein was performed according to Doumas et.al. (1981), albumin by Drupt, (1974) and serum globulin wase calculated as the difference between serum total protein and albumin . HI titer was determined according to Takatsy (1956). Serum AST, and ALT activities were measured according to (Reitman and Frankel, 1957), Createnine (Henry, 1979) and uric acid (Baraham and Trinder, 1972).

\section{Statistical analysis:}

Data were statistically analyzed using one-way analysis of variance and Duncan's multiple range test was used for comparison between means (SAS, 1998). 


\section{RESULTS AND DISCUSSION}

The obtained data presented in tables from (1) to (7) showed that the administration semduramicin resulted in a significant decrease of the phagocytic activity, serum globulin and HI titer. Additionally, semduramicin decreased the relative weights of bursa. On the other hand, the administration of either diclazuril or semduramicin has no significant effects on the levels of serum AST, ALT, createnine and uric acid. Moreover, there was no significant changes in blood cell count between control and treated groups.

Table (1): The effect of diclazuril and semduramicin on phagocytic activity and phagocytic index.

\begin{tabular}{|c||c|c||}
\hline Treatments & phagocytic activity & Phagocytic index \\
\hline \hline Semduramicin & $21.50+0.45 \mathrm{bc}$ & $2.77+0.24$ \\
\hline Diclazuril & $22.80+0.64 \mathrm{ab}$ & $2.72+0.17$ \\
\hline Control & $24.10+0.52 \mathrm{a}$ & $2.93+0.19$ \\
\hline
\end{tabular}

Means in the same row bearing different letters, differ significantly $(P<0.05)$

Table (2): The effect of diclazuril and semduramicin on blood cell count.

\begin{tabular}{||c||c||c||}
\hline Treatments & Total RBcs count & Total leukocytic count \\
\hline Semduramicin & $\left(10^{6} / \mu \mathrm{l}\right)$ & $(\mathrm{X} 1000 \mathrm{cells} / \mathrm{cmm})$ \\
\hline Diclazuril & $3.25 \mathrm{~ns} \pm 0.01$ & $27.9 \mathrm{~ns} \pm 2.51$ \\
\hline Control & $3.45 \mathrm{~ns} \pm 0.02$ & $28.7 \mathrm{~ns} \pm 1.47$ \\
\hline
\end{tabular}

Ns =non significant 
Pharmacological Study On The Effect Of Diclazuril ...

Table (3): The effect diclazuril and semduramicin on differential leukocytic count

\begin{tabular}{|c|c|c|c|c|c|}
\hline Treatments & $\begin{array}{c}\text { Blood } \\
\text { monocytes (\%) }\end{array}$ & $\begin{array}{c}\text { Blood } \\
\text { lymphocytes }(\%)\end{array}$ & $\begin{array}{c}\text { Blood } \\
\text { heterophils }(\%)\end{array}$ & $\begin{array}{c}\text { Blood } \\
\text { esinophils (\%) }\end{array}$ & $\begin{array}{c}\text { Blood } \\
\text { basiophils (\%) }\end{array}$ \\
\hline Semduramicin & $9.5 \mathrm{~ns} \pm 0.24$ & $63.2 \mathrm{~ns} \pm 1.36$ & $23.6 \mathrm{~ns}+0.80$ & $2.4 \mathrm{~ns} \pm 0.41$ & $1.3 \mathrm{~ns} \pm 0.37$ \\
\hline Diclazuril & $9.7 \mathrm{~ns} \pm 0.26$ & $63.0 \mathrm{~ns} \pm 0.5$ & $23.6 \mathrm{~ns}+0.58$ & $2.4 \mathrm{~ns} \pm 0.45$ & $1.3 \mathrm{~ns} \pm 0.37$ \\
\hline Control & $10.20+0.41$ & $62.7 \pm 0.8$ & $23.2 \pm 0.45$ & $2.5 \pm 0.23$ & $1.4 \pm 0.42$ \\
\hline
\end{tabular}

Ns =non significant

Table(4): The effect of diclazuril and semduramicin on the total serum protein, albumin and globulin (g/dL).

\begin{tabular}{|c|c|c|c|}
\hline Treatments & Total serum protein & Serum albumin & Serum globulin \\
\hline Semduramicin & $4.35 \pm 0.39^{\mathrm{b}}$ & $2.34 \pm 0.13^{\mathrm{a}}$ & $2.01 \pm 0.13^{\mathrm{c}}$ \\
\hline Diclazuril & $4.24 \pm 0.19^{\mathbf{b}}$ & $1.92 \pm 0.12^{\mathrm{b}}$ & $2.33 \pm 0.09^{\mathrm{b}}$ \\
\hline Control & $5.03 \pm 0.31^{\mathrm{a}}$ & $2.09 \pm 0.15^{\mathrm{b}}$ & $2.94 \pm 0.19^{\mathrm{a}}$ \\
\hline
\end{tabular}

Means in the same row bearing different letters, differ significantly $(\mathrm{P}<0.05)$

Table (5): The effect of diclazuril and semduramicin on the haemagglutination inhibiting (HI) antibody titer (log 2), feed conversion and protection.

\begin{tabular}{|c|c|c|c|}
\hline Treatments & HI titer & Feed conversion & Protection \% \\
\hline Semduramicin & $5.0 \pm 0.531^{\mathrm{b}}$ & $2.108 \pm 0.024^{\mathrm{a}}$ & $72 \%$ \\
\hline Diclazuril & $6.3 \pm 0.412^{\mathrm{a}}$ & $2.07 \pm 0.027^{\mathrm{a}}$ & $80 \%$ \\
\hline Control & $6.5 \pm 0.542^{\mathrm{a}}$ & $1.856 \pm 0.018^{\mathrm{b}}$ & $82 \%$ \\
\hline
\end{tabular}

Means in the same row bearing different letters, differ significantly $(\mathrm{P}<0.05)$

Table (6): The effect of diclazuril and semduramicin on the Serum AST, $\operatorname{ALT}(\mathrm{U} / \mathrm{L})$, Createnine and uric acid.

\begin{tabular}{|c|c|c|c|c|}
\hline Treatments & AST & ALT & $\begin{array}{l}\text { Createnine } \\
(\mathrm{mg} / \mathrm{dL})\end{array}$ & uric acid (mg/dL) \\
\hline Semduramicin & $69.88 \mathrm{~ns} \pm 2.27$ & $21.1 \pm \mathrm{ns} 11 . .24$ & $1.82 \mathrm{~ns} \pm 0.13$ & $15.57 \mathrm{~ns} \pm 0.54$ \\
\hline Diclazuril & $75.02 \mathrm{~ns} \pm 2.54$ & $0.85 \pm$ ns $10 . .66$ & $2.03 \mathrm{~ns} \pm 0.18$ & $15.26 \mathrm{~ns} \pm 0.68$ \\
\hline Control & $74.59 \pm 1.78$ & $0.67 \pm 10 . .54$ & $2.11 \pm 0.15$ & $14.93 \pm 0.51$ \\
\hline
\end{tabular}

Ns =non significant

Kafrelsheikh Vet. Med. J. Vol. 11 No. 2 (2013) 
Table (7): The effect of diclazuril and semduramicin on the relative weight of bursa, spleen and thymus.

\begin{tabular}{||c||c||c||c||}
\hline Treatments & Sursa relative weight & Spleen relative weight & Thymus relative weight \\
\hline \hline Semduramicin & $1.513 \pm 0.231^{\mathrm{b}}$ & $1.783 \pm 0.138$ & $2.211 \pm 0.182$ \\
\hline Diclazuril & $2.415 \pm 0.165^{\mathrm{a}}$ & $1.769 \pm 0.125$ & $2.136 \pm 0.236$ \\
\hline Control & $2.391 \pm 0.152^{\mathrm{a}}$ & $1.810 \pm 0.143$ & $2.245 \pm 0.193$ \\
\hline
\end{tabular}

Means in the same row bearing different letters, differ significantly $(\mathrm{P}<0.05)$

In the light of the present findings, it could be stated that semduramicin administered in the recommended dose significantly suppressed the chickens immune response to (NDV) vaccine. The depressed response was reflected as decreased phagocytic activity, HI titer, serum globulin, bursa relative weight and the protective power of NDV vaccine. The same results were also obtained by Abo-Zahra (1997). The author recorded that administration of maduramicin decreased HI titer, serum globulin and the protection of chickens vaccinated with NDV vaccine. Also, Seif (2008) concluded that semduramicin (25ppm) had immunosuppressive effects on broiler.

The data in table (2) and table (3) cleared that the recommended doses of semduramicin or diclazuril did not elicited any significant effects on both the total and differential leucocytic counts. These results are in accordance with El-Kahkey, (1998) who found out that $\overline{\overline{\text { Kafrelsheikh Vet. Med. J. Vol. } 11 \text { No. } 2 \text { (2013) }}}$ 
administration of semduramicin (25ppm) had no significant effects on the total and differential leucocytic counts in broilers. Our results are further in harmony with those reported by Abedel-Hafez, (2004) who stated that diclazuril given in the recommended doses evoked no significant changes on the total and differential leucocytic counts of chickens.

Our results demonstrated that semduramicin significantly increased the feed conversion of birds - The previous results agree with Singh and Gupta (2003). The outher recorded that chicken fed with maduramicin medicated feed at 5 and $10 \mathrm{ppm}$ for 21 days showed growth retardation. Moreover, Hassanpour et al.,(2010) reported that semduramicin have adverse effects on chicken performance and intestinal morphology, especially villus dimensions and absorptive surface.

Feed conversion was not significantly improved in birds fed diclazuril. The fore- mentioned finding fits neatly with those narrated by Vanparijs et al. (1989). The authors reported that administration of diclazuril at recommended doses for 42 days did not induce any significant changes in feed conversion of chickens

The obtained data in this work showed that AST, AST, createnine and uric acid levels were not significantly changed in treated groups and this denoting neither hepatotoxic nor nephrotoxic effect of semduramicin and diclazuril . The finding reported by Chapman, (2001), Nebbia et al. (1999)and EFSA, (2011) are in agreement with the present result. 


\section{REFERENCES}

- Abedel-Hafez, A. M. G. (2004): Pharacological study on the effects of diclazuril and flavomycin alone and combination on performance and immune response in chickens. Thesis for Ph.D. (pharmacology), Faculty of veterinary medicine, Kafer El-Sheikh University.

- Abd El Lateif, A. E. (1993): Side and latent effect of the concurrent use of maduramycin (Cygo $®)$ and avoparcin (Avotan $\left.{ }^{\circledR}\right)$ on broilers. Thesis for Ph.D. (pharmacology), Faculty of veterinary medicine, Zagazig University.

- Abo-Zahra, A. A. (1997): Effect of Mauramicin on the immune response of chickens vaccinated with New Castle disease virus vaccine.

- Barry L., Ghamon, U., John R., and Glisson A. (1989): In vitro microbial activity of avian pertoneal macrophages. Avian diseases. 23(1):177-181.

- Baraham, D. and Trinder, P. (1972): Enzymatic determination of uric acid. Analyst. 97: 142-145.

- Chapman, H.D. (1989): Field isolates of E.tenella : sensitive todiclazuril ,maduramicin, narasin,salinomycin and a mixture of nicarbazin/narasin. Parasitol.75 (2):3-5.

- Chapman HD. (2001): Use of anticoccidial drugs in broiler chickens in the United States: Analysis for the years 1995 to 1999. Poultry Science, 2001; 80:572-580. 
- Doumas, B.T.; Bayso, D.D.; Carter, R.J.; Peters, T. and Schaffer, R. (1981): Determination of total serum protien. Clin. Chem., 27:16421643.

- Dowling, L. (1992): Ionophore toxicity in chickens: Review of Pathology and Diagnosis. Avian Path., 21: 355-368.

- Drupt F.(1974): Colorimetric method for determination of albumin .Pharm.Bio.,9:777.

- EFSA (2011): Panel on Additives and Products or Substances used in Animal Feed (FEEDAP), 2011. Scientific Opinion on safety and efficacy of Clinacox ${ }^{\circledR} 0.5 \%$ (diclazuril) for turkeys for fattening. EFSA Journal, 9 (4): 2115.

- El-Kahkey, M. (1998): Effect of semiduramicin on the immune response in chickens vaccinated with NewCastle diease virus . Thesis for Ph.D.(pharmacology ),Faculty of veterinary medicine, Zagazig University.

- Falz S.D., Lee B.L., Nowakoski L.H. and Conder G.A.(1988): Anticoccidial evaluation of halofuginone, lasalocid, maduramicin, monensin and salinomycin. Vet.Parasitol.28:1-9

- Hasan, S., El-sabbagh, F. and Hesham, S. (1999): Effect of diclazuril and performance and immune response in rabbits .Al-azhar Med.J.,28(2):183-191.

- Hassanpour, H., Bahadoran, S., Koosha,S., Askari, E., and Homai, S. (2010): Effect of Diclazuril, Semduramicin, Salinomycin and Maduramycin as Preventive Anticoccidial Drugs on Chicken Intestinal Morphology Global Veterinaria 5 (1): 01-05, 2010. 
- Henry R.J. (1979): Colotrimeric method for determination of serum creatinine. Clinical chemistry, principles and Techniques. $2^{\text {nd }}(e d)$, Harper and Row p 525. J. Antimicrobial chemother, 21: 195-200.

- Kandeel, M. (2002): The effect of diclazuril and semiduramicin asprophylactic and therapeutic treatment on broilers infected with Eimeria teneella. Athesis for M.V.Sc(pharmacology),Faculty of Veterinary Medicine, Tanta University

- kutzer, E., Loewenstein, M. and Mitterlehner, A. (1988): Effectiveness and tolerance of robenindine and diclazuril against coccidiosis in rabbits.Praktische Tierarzt.,76(3):250-252.

- Nebbia C, Ceppa L, Dacasto M, Carletti M, Nachtmann C. (1999): Oxidative metabolism of monensin in rat liver microsomes and interactions with tiamulin and other chemotherapeutic agents: Evidence of the involvement of cytochrome P-450 3\$ subfamily. Drug Metabolism and Disposition 1999; 27:1039-1044.

- Natt, M.P and Herrick, C.A. (1952): A new blood diluent for counting the red and white blood cells of the chicken. Poultry Science., 31:335.

- Reitman, S. and Frankel, S. (1957): Colorimetric determination of GOT and GPT activity. Am. J. Clin. Path., 28: 56.

- Riviere J. E., Papich, M. G. and Adams, R., H. (2009): Veterinary Pharmacology and therapeutics. ${ }^{9 \text { th }}$ edition . Blackwell publishing

- Salisch H. and Friederichs M. (1991): Efficacy of salinomycin and mauramicin against E. mitis. In chickens. Archive fur Geflugelkunde 55(3):115-117. 
- Salisch H. and Shakshouk A. G. (1990): Efficacy of diclazuril and four ionophorous anticoccidial against E.tenella E.acervulina .Archive fur Geflugelkunde53(3):11-119

- SAS. (1998): SAS, procedure Guide.Version b 12 Ed. "SAS" Institute Inc., Cary, NC, USA

- Schalm,O.W., Jain,N.C. and Carroll, E. J. (1975):Veterinary Haematology, $3^{\text {rd }}$ ED. Lea and Febiger, Philadelphia Tsou H.R.,Rajin C., Fiala R Mowery G., Bullock M.,

- Seif A.S.A. (2008): Immunopharmacolgical study on antiparasitics widely used in veterinary practice. Thesis for Ph.D.(pharmacology), Faculty of veterinary medicine, Kafrelsheikh University.

- Singh T. and Gupta RP(2003): Clinico-haematological and mineral studies on experimental maduramicin toxicity in chickens. Vet Parasitol 2003;116:345-53.

- Border B., James J., Martin J. and Martin O. (1984): Biosynthesis of the antibiotic maduramicin, origin of the carbon and oxygen atoms as well as the $\mathrm{C}_{13}$ NMR assignments. J.Antibio.37:1651-1663.

- Takatsy, G. Y. (1956): The use of spiral loop in serological and virological micromethods. Acta Microbiologica Acad. Sci. Hung.,3:197.

- Vanparijs, O., R. Marsboom, L. Hermans, and L. Van der Flaes. (1989): Diclazuril, a new broad spectrum anticoccidial drug in chickens. 2. Battery trials. Poultry Sci 68:496-500. 
دراسة فارماكولوجيه علي تأثير ات الديكلازوريل و السيمديور امايسين على معدلات الأداء

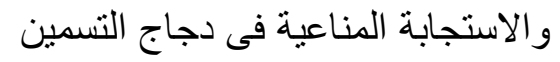

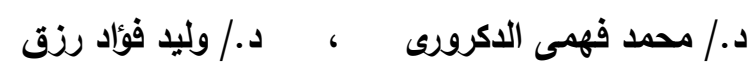

$$
\text { معهد بحوث صحة الحيوان - كفر الثيخ }
$$

استهدف هذا البحث دراسة تأثثرات استخدام الديكلازوريل والسيمديورامايسين على معدلات الأداء والاستجابة المناعية فى دجاج التسمين من نوع الهبرد. قسمت الكتاكيت إلى ثلاث مجموعات منساوية كل منهـا تحتوى على 30 كتكوت المجموعـة الأولى أضـيف إليهـا السيمديورامايسين (25جزء في المليون). بينما المجموعة الثانية أضيف إليها الديكلازوريل (1 جزء فى المليون) أما المجموعة الأخيرة (مجموعه ضابطه) أعطيت عليقه أساسيه فقط: عند اليوم 18 ثم تحصين جميع الطيور بلقاح لاسوتا و عند 21 يوم تم العدوى بفيرس النيوكاسل عند يوم 25 من بدايـة التجربـة تم اخذ عينـات الدم من الطيور في كل المجموعات لإجراء عدد من الفحوص المختلفة وكذلك تم حساب الوزن النسبي للغدة الزعتريـه وغدة البرسـافابريش والطحسال في كل مجموعـه. معدل التحويـل الغذائي ونسبه النفوق تم نسجيلهم بنهايه التجربة عند عمر 45 يوم. وقد اتضح من هذه الدراسة أن استخدام كلا العقارين بالجرعات السابقة لم يحدث أي تأثير

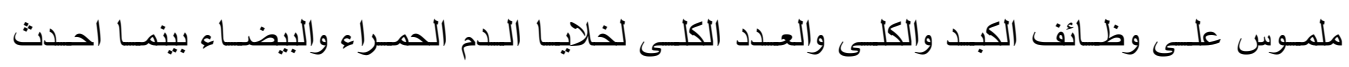
السيمديورامايسين نقصا ملموسا في النشاط البلعمي و مستوى الجلوبيولين لمصل الدم والأجسام المناعية لكنع التلازن الدموى ضد فيروس النيوكاسل و الوزن النسبى لغدة البرسافابريش. 